DOI: $10.19195 / 0137-1134.114 .21$

\author{
KAROL KICZKA \\ Uniwersytet Wrocławski \\ karol.kiczka@uwr.edu.pl
}

\title{
Z TEORII I PRAKTYKI SAMORZĄDU TERYTORIALNEGO
}

\begin{abstract}
Abstrakt: Zagadnienia prawne samorządu terytorialnego są przedmiotem zainteresowania prawoznawstwa. Konstytucyjnoprawne i prawnomiędzynarodowe uwarunkowania sytuują samorząd terytorialny jako ważny oraz trwały element struktury organizacyjnej demokratycznego państwa prawnego. Dookreślanie statusu samorządu terytorialnego przez czynnik parlamentarny i w drodze rozporządzeń skutkuje niekiedy odchodzeniem od odnośnych wymogów konstytucyjnych i międzynarodowych. Dlatego tak doniosłe jest zagwarantowanie funkcjonowania bezstronnej, niezależnej, niezawisłej i sprawnej władzy sądowniczej w dziedzinie organizacji i funkcjonowania samorządu terytorialnego w nowoczesnym państwie.
\end{abstract}

Słowa kluczowe: samorząd terytorialny, demokratyczne państwo prawne, władza sądownicza

\section{WPROWADZENIE}

Tematyka jurydyczna samorządu terytorialnego to głównie domena prawa publicznego, która jest przedmiotem badań szczegółowych dyscyplin prawoznawstwa. Materie odnoszące się do samorządu terytorialnego mają bardzo ważne znaczenie praktyczne dla funkcjonowania państwa, określonych wspólnot samorządowych i sytuacji człowieka we współczesnym świecie. Konstytucja Rzeczypospolitej Polskiej stanowi w szczególności, że ustrój terytorialny Rzeczypospolitej Polskiej zapewnia decentralizację władzy publicznej. Zasadniczy podział terytorialny państwa, uwzględniający więzi społeczne, gospodarcze lub kulturowe i zapewniający jednostkom terytorialnym zdolność wykonywania zadań publicznych, określa ustawa. Ogół mieszkańców jednostek zasadniczego podziału terytorialnego - jak przyjmuje ustrojodawca — stanowi z mocy prawa wspólnotę samorządową. Samorząd terytorialny uczestniczy w sprawowaniu władzy publicznej. Przysługującą mu w ramach ustaw istotną część zadań publicznych samorząd wykonuje w imieniu własnym i na własną odpowiedzialność. Samorząd teryto- 
rialny wykonuje zadania publiczne niezastrzeżone przez Konstytucję lub ustawy dla organów innych władz publicznych ${ }^{1}$.

Unia Europejska w odniesieniu do samorządu terytorialnego zajmuje odmienną pozycję niż stanowisko Konstytucji RP. Unia Europejska - w świetle Traktatu o Unii Europejskiej - szanuje równość państw członkowskich wobec traktatów, jak również ich tożsamość narodową, nierozerwalnie związaną z ich podstawowymi strukturami politycznymi i konstytucyjnymi, w tym - co akcentujemy - w odniesieniu do samorządu regionalnego i lokalnego. Szanuje podstawowe funkcje państwa, zwłaszcza funkcje mające na celu zapewnienie jego integralności terytorialnej, utrzymanie porządku publicznego oraz ochronę bezpieczeństwa narodowego. W szczególności bezpieczeństwo narodowe pozostaje w zakresie wyłącznej odpowiedzialności każdego państwa członkowskiego².

Pozostawienie kwestii prawnoustrojowych - samorządu terytorialnego w kręgu dominacji suwerennych kompetencji państw członkowskich Unii Europejskiej akcentuje Leon Kieres. Autor wskazuje, iż raczej mogliśmy obserwować defensywną postawę wspólnot gospodarczych wobec problematyki samorządu terytorialnego. Prawnomiędzynarodowe regulacje tej problematyki należały do domeny Rady Europy. Unia Europejska, uprzednio Europejska Wspólnota Gospodarcza, w opinii L. Kieresa raczej rejestrowała wyniki współpracy państw członkowskich Rady Europy — zarówno co do zbliżania (harmonizacji) pozycji samorządu terytorialnego w systemach ustrojowych państw członkowskich, jak i współpracy międzynarodowej jednostek samorządu terytorialnego. Jeżeli można mówić o zainteresowaniu UE samorządem terytorialnym, to uwzględniano ich

1 Art. 15, 16 i 163 Konstytucji Rzeczypospolitej Polskiej z dnia 2 kwietnia 1997 r. (Dz.U. Nr 78, poz. 483, sprost. Dz.U. z 2001 r. Nr 28, poz. 319 z późn. zm.; dalej: Konstytucja RP, Konstytucja). Por. J. Panejko, Geneza i podstawy samorząu europejskiego, Paryż 1926; T. Bigo, Związi publiczno-prawne w świetle ustawodawstwa polskiego, Warszawa 1928; W.S. Wacholz, Istota i prawo związków publicznych (publiczne osoby związkowe), Warszawa 1928; M. Dembiński, Osobowość publiczno-prawna samorządu w świetle metody dogmatycznej i socjologicznej, Wilno 1934; Z. Niewiadomski, Samorząd w warunkach państwa kapitalistycznego, Warszawa 1988; B. Dolnicki, Modele samorzadu terytorialnego w Europie i w Polsce, Katowice 1994; Z. Leoński, Samorząd w Polsce. Istota. Formy. Zadania, Poznań 1998; Samorzad terytorialny i administracja w wybranych krajach. Gmina w państwach Europy Zachodniej, red. J. Jeżewski, Wrocław 1999; I. Skrzydło-Niżnik, Model ustroju samorządu terytorialnego w Polsce na tle zagadnień ustrojowego prawa administracyjnego, Kraków 2007; P. Lisowski, Relacje strukturalne w polskim samorządzie terytorialnym, Wrocław 2013; Aktualne problemy funkcjonowania samorzadu terytorialnego, red. E. Ura, E. Ferent, S. Pieprzny, Rzeszów-Sandomierz 2017.

2 Art. 4 ust. 4 Traktatu o Unii Europejskiej (wersja skonsolidowana Dz.Urz. C 326 z 26.10.2012, s. 13-46; dalej: TUE). Por. M. Kulesza, K. Galus, M. Tułowiecki, Harmonizacja prawa polskiego w zakresie przepisów dotyczących samorządu terytorialnego, Warszawa 2001; A. Cieśliński, Stosowanie prawa wspólnotowego w praktyce organów samorzadowych, [w:] Samorzą terytorialny $w$ Polsce wobec wyzwań integracji europejskiej, red. J.P. Tarno, Zielona Góra 2003, s. 31; T. Szewc, Dostosowanie prawa polskiego do zasad Europejskiej Karty Samorzadu Terytorialnego, Bydgoszcz 2006. 
sytuację prawną wewnętrzną oraz ustaloną $\mathrm{w}$ aktach międzynarodowych przede wszystkim w związku z pewnymi wyzwaniami i celami współpracy, co także dotyczyło pozycji państw kandydujących i stowarzyszonych ${ }^{3}$.

Celem niniejszego opracowania jest prezentacja i analiza zawartości niektórych wypowiedzi doktryny podejmującej tematykę samorządu terytorialnego określanego niekiedy - w odróżnieniu od samorządu zawodowego (osobowego, specjalnego) - samorządem politycznym, z uwzględnianiem pewnych praktycznych aspektów jego działalności odnotowywanych w wybranych judykatach. Dążenie do osiągnięcia założonego celu może być wsparciem do dalszego prowadzenia pogłębionych badań w kierunku ustalenia i weryfikowania stanowiska prawnego samorządu terytorialnego w strukturze RP.

\section{SAMORZĄD TERYTORIALNY W NIEKTÓRYCH OPINIACH NAUKOWYCH}

Pierwszy Polski Kongres Nauk Administracyjnych (dalej: Kongres) odbyty w Poznaniu w dniach 20-23 czerwca 1929 roku - w kontekście tytułowej problematyki wskazywał, że przy podziale administracyjnym państwa należy dążyć do tworzenia takich jednostek administracyjnych, które byłyby regionami wyodrębniającymi się pod względem warunków i potrzeb miejscowych, stawiającymi administracji publicznej jasne i określone zadania. Uwypuklano też, że tylko administracja lokalna może ożywić i należycie, jak wyrażono - wyzyskać — dla dobra państwa wszelkie siły społeczne i materialne kraju. W związku z tym Kongres wskazywał na potrzebę dostosowania środków finansowych samorządu terytorialnego do jego zakresu działania jako jedną z najpilniejszych potrzeb administracji publicznej ${ }^{4}$.

${ }^{3}$ L. Kieres, Prawo europejskie wobec samorzadu terytorialnego, [w:] Samorzad - finanse - nadzór i kontrola. XX-lecie Regionalnych Izb Obrachunkowych, red. R.P. Krawczyk, M. Stec, Warszawa 2013, s. 20. Por. idem, Analiza zgodności polskiego prawa samorzadu terytorialnego z Europejska Karta Samorządu Terytorialnego, „Samorząd Terytorialny” 1998, nr 9; H. Izdebski, Rada Europy. Organizacja demokratycznych państw Europy i jej znaczenie dla Polski, Warszawa 1996; J. Jaskiernia, Zgromadzenie Parlamentarne Rady Europy, Warszawa 2000; J. Kaczmarek, Rada Europy, Wrocław 2002; Polska i Rada Europy: 1990-2005, red. H. Machińska, Warszawa 2005; F. Benoît-Rohmer, H. Klebes, Prawo Rady Europy. W stronę ogólnoeuropejskiej przestrzeni prawnej, przeł. M.A. Nowicki, Warszawa 2006; 60 lat Rady Europy. Tworzenie $i$ stosowanie standardów prawnych, red. H. Machińska, Warszawa 2009.

4 Z I-go Polskiego Kongresu Nauk Administracyjnych w Poznaniu (20-23 czerwca 1929), „Ruch Prawniczy, Ekonomiczny i Socjologiczny” 1929, s. 1224. Por. M. Kulesza, Niektóre zagadnienia prawne definicji samorzadu terytorialnego, „Państwo i Prawo” 1990, nr 1, s. 23; Studia nad samorzadem terytorialnym, red. A. Błaś, Wrocław 2002; Z. Niewiadomski, Samorząd terytorialny $w$ Konstytucji RP [komentarz do art. 15, art. 16 oraz do art. 163-172], „Samorząd Terytorialny” 2002, nr 3, s. 3; J. Stępień, Samorząd terytorialny w konstytucyjnym ustroju państwa, [w:] Księga XX-lecia orzecznictwa Trybunału Konstytucyjnego, red. M. Zubik, Warszawa 2006, s. 615. 
Przywoływane stanowisko pozostawało w związku z ustaleniami poczynionymi w fundamentalnej i aktualnej pracy Zwiazki publiczno-prawne w świetle ustawodawstwa polskiego T. Bigo: jeśli doskonała demokracja oznacza zespolenie (identyfikację) jednostki ze zbiorowością, to samorząd terytorialny może być pośrednim etapem tego procesu, jego ogniwem. Tylko wtedy, jak pisze dalej autor, gdy pojmuje się omawiany samorząd jako narzędzie walki z rządem centralnym, dochodzi się do konkluzji, że oznacza on rozbicie jedności państwa demokratycznego. Jeśli natomiast widzi się w samorządzie terytorialnym formę decentralizacji, to raczej popiera on proces zespolenia jednostki z państwem ${ }^{5}$.

W tym krótkim przeglądzie samorządu terytorialnego — jak pisze F. Longchamps - uderzają pewne swoiste znamiona ustrojowe: że organy samorządu pochodzą nie z mianowania (,z góry”) przez władze rządowe, lecz zazwyczaj z wyboru („od dołu”) spośród miejscowych ludzi, i że decydowanie odbywa się tu w sposób zbiorowy - pewien zespół ludzi naradza się i głosuje, a decyzja jest wynikiem tego głosowania ${ }^{6}$.

Autor dalsze znamię samorządu terytorialnego upatruje w tym, że to poszczególne związki samorządu terytorialnego (gmina wiejska, miasto itp.) — jednostki samorządu terytorialnego - są odrębnymi osobami prawnymi. Mimo że zagadnienie „osoby prawnej” nastręcza w teoretycznych rozważaniach o prawie wiele trudności, to w praktycznej kulturze prawnej pojęcie osoby prawnej odgrywa od dawna rolę zupełnie niezbędną. Mianowicie porządek prawny traktuje pewne zespoły ludzi lub zespoły majątkowe, urządzenia itp., pod względem prawnym tak, jak gdyby były pojedynczymi ludźmi: mogą więc mieć własność czegoś, mogą mieć jakieś prawa, jakieś obowiązki, słowem uważane są za tak zwane podmioty prawa. I dotyczy to nie tylko spraw majątkowych; także i tam, gdzie chodzi o władzę - o możność rozkazywania ludziom — uważa się, że prawo do tego mają właśnie takie zespoły — osoby prawne; na przykład gmina, miasto czy wreszcie państwo są takimi „osobami prawnymi”. Poszczególni ludzie działają „za nie”, ,w ich imieniu”, „w ich zastępstwie” czy jak to się określa. Dzięki takiemu pojmowaniu państwa jako osoby prawnej tłumaczy się to, że jeżeli minister spraw zagranicznych podpisuje jakąś umowę międzynarodową, wtedy nabywa prawa albo zobowiązuje się do czegoś nie on sam, lecz państwo - owa osoba prawna, w której imieniu działał ${ }^{7}$.

Otóż, stwierdza dalej F. Longchamps: każdy związek samorządu terytorialnego, każda gmina wiejska, każde miasto itp. występują w porządku prawnym jako odrębne osoby prawne: odrębne przede wszystkim od państwa (które też jest osobą

5 T. Bigo, op. cit., s. 218-219.

${ }^{6}$ F. Longchamps, Co każdy obywatel powinien wiedzieć o administracji państwowej, Warszawa 1948, s. 36.

7 Ibidem, s. 37. 
prawną), ale odrębne też od poszczególnych ludzi, którzy na ich terenie mieszkają. Sens tego polega na tym, że miasto ma pewne prawa i obowiązki wobec swego mieszkańca, które jednak nie są prawami i obowiązkami państwa.

Ujmijmy to, jak akcentuje autor, w jednym zdaniu: stanowisko prawne każdego poszczególnego związku samorządu terytorialnego jest odrębne od stanowiska prawnego państwa. Toteż nie ma między poszczególnymi związkami samorządu terytorialnego tego podporządkowania hierarchicznego, które jest znamienne we władzach administracji rządowej. Związki samorządu terytorialnego nie są „podległe służbowo” ani związkom samorządowym wyższego stopnia, ani też ministrom. Wyjątek zachodzi wyłącznie, wówczas gdy na przykład prezydent miasta wykonuje funkcje ,zlecone" $\mathrm{z}$ administracji rządowej ${ }^{8}$.

Co do zakresu działania, w opinii F. Longchampsa administracji rządowej powierzone są potrzeby powszechne, kierowane jednolicie w całym państwie; do samorządu terytorialnego należą potrzeby miejscowe. Istotne wydaje się, że sprawami, które mają znaczenie miejscowe, zarządzają miejscowi ludzie, powołani przez wybór, że używają do tego miejscowych zasobów i że mają swobodę w stosunku do administracji rządowej' ${ }^{9}$.

Wskazane tu niektóre z cech swoistych samorządu terytorialnego rozważa M. Zimmermann, który zaznacza, że władza może być organem państwa, jednak istnieją władze będące organami innych podmiotów, na przykład organy gminne. Wykonują one władzę nie w imieniu państwa, lecz w imieniu gminy jako odrębnego od państwa podmiotu. Systemy decentralizacji, jak wykazuje M. Zimmermann, mogą być różne: administracja zdecentralizowana może być wykonywana w imieniu państwa bądź też w imieniu innych podmiotów prawa publicznego ${ }^{10}$.

Wykonana przez J. Korczaka analiza wybranych konstytucji kontynentalnych państw europejskich pokazuje, że nie istnieje żaden standard jurydyczny samorządu terytorialnego na poziomie ustrojowym (konstytucyjnym). Problem funkcjonowania samorządu terytorialnego $\mathrm{w}$ państwie, tak przecież istotny dla ustrojów państw demokratycznych, w opinii autora może być rozwiązany zarówno bardzo szczegółowo, jak i bardzo pobieżnie, mogą to być regulacje dotykające rzeczy iście fundamentalnych - istota samorządu, miejsce w ustroju organów władzy publicznej i wzajemne relacje między nimi, gwarancje samodzielności jednostek

8 Ibidem, s. 38.

9 Ibidem, s. 39. Por. S. Jędrzejewski, H. Nowacki, Kontrola administracji publicznej. Kontrola a nadzór. Struktura systemu. Instytucje, Toruń 1995; B. Dolnicki, Nadzór nad samorządem terytorialnym, Katowice 1993; M. Zdyb, Samorzad a państwo. Nadzór na samorzadem, Lublin 1993.

10 M. Zimmermann, Nauka administracji i polskie prawo administracyjne, cz. 1, Poznań 1949, s. 62. Por. J. Starościak, Decentralizacja administracji, Warszawa 1960; J. Jeżewski, Dekoncentracja terytorialna administracji jako zasada prawa administracyjnego we Francji, Wrocław 2004; S. Fundowicz, Decentralizacja administracji publicznej w Polsce, Lublin 2005; J. Niczyporuk, Dekoncentracja administracji publicznej, Lublin 2006. 
samorządu — ale też niemające dla samego istnienia samorządu terytorialnego i jego jednostek znaczenia gwarancje praw grup etnicznych ${ }^{11}$.

Polskie reformy w zakresie odbudowy samorządu terytorialnego budziły, jak pisze Jerzy Regulski, ogromne zainteresowanie za granicą. Wiele rządów i organizacji pozarządowych zgłaszało gotowość pomocy w tym obszarze. Z natury rzeczy oferty te były kierowane do Pełnomocnika Rządu do spraw Reformy Samorządu Terytorialnego jako jedynego organu związanego z reformą samorządową. Bez wspomnianej pomocy rozwój demokracji lokalnej w Polsce przebiegałby znacznie wolniej. Reforma samorządowa, podobnie zresztą jak reformy gospodarcze, znacznie wyżej była notowana na Zachodzie niż w Polsce. Należy też zdaniem autora podkreślić ogromną pomoc merytoryczną, jakiej udzieliła wówczas Polsce Rada Europy. Europejska karta samorządu lokalnego (EKSL) ${ }^{12}$, opracowana w ramach Rady Europy na podstawie doświadczeń krajów demokratycznych, była wzorem, do którego nawiązywano w zakresie omawianych przemian w Polsce ${ }^{13}$.

Zrealizowane przez M. Kuleszę badania aktywności samorządu terytorialnego pokazują, że polskie rozwiązania, mimo zupełnie wystarczających podstaw konstytucyjnych i ustawowych, w praktyce zmierzają w kierunku ograniczenia samodzielności podstawowej jednostki samorządu terytorialnego. Autor zauważa, że wbrew postanowieniu art. 3 ust. 1 EKSL, że ,Samorząd lokalny oznacza prawo i zdolność społeczności lokalnych, w granicach określonych prawem, do kierowania i zarządzania zasadniczą częścią spraw publicznych na ich własną odpowiedzialność i w interesie ich mieszkańców", w przedstawionym ujęciu radykalnemu zawężeniu ulega „prawo”, a w ślad za tym — „zdolność” społeczności lokalnych do zarządzania swoimi sprawami. Dzieje się to przez wypieranie ogólnych podstaw prawnych i zastępowanie ich rozwiązaniami szczegółowymi i kazuistycznymi także tam, gdzie nie przewiduje się kompetencji władczych. Rozwiązania szczegółowe, w opinii M. Kuleszy, które przy działalności organizatorskiej zazwyczaj są niedoskonałe i najczęściej spóźnione, służą wiązaniu samorządu terytorialnego, by zawsze (również w sferze niewładczej) działał ,w ramach i na podstawie prawa”, a nie tylko „w ramach prawa”. Autor trafnie wskazuje, że EKSL głosi „W granicach określonych prawem”, a nie „na podstawie ustawy”. W ten sposób

11 J. Korczak, Konstytucyjne podstawy struktury i funkcji samorzadu terytorialnego, [w:] System Prawa Administracyjnego, t. 2. S. Biernat et al., Konstytucyjne podstawy funkcjonowania administracji publicznej, Warszawa 2012, s. 176. Por. K. Chorąży, Zagadnienia ustroju lokalnego Francji, Lublin 1998, s. 52; M. Miemiec, Gmina w administracji publicznej Republiki Federalnej Niemiec, Wrocław 2007.

12 Europejska karta samorządu lokalnego sporządzona w Strasburgu 15 października 1985 r. ratyfikowana przez Rzeczpospolitą Polską w dniu 26 kwietnia 1993 r. (Dz.U. z 1994 r. Nr 124, poz. 607).

13 J. Regulski, Samorzą III Rzeczypospolitej. Koncepcje i realizacja, Warszawa 2000, s. 88. Por. T. Rabska, Samorzad terytorialny w strukturze aparatu państwa (perspektywy przebudowy administracji lokalnej), „Ruch Prawniczy, Ekonomiczny i Socjologiczny” 1993, z. 3, s. 23. 
zdaniem M. Kuleszy następuje zanegowanie zasadniczych mechanizmów i sensu samodzielności komunalnej i w konsekwencji upodobnienie samorządu terytorialnego do hierarchicznie podporządkowanych organów administracji rządowej, które muszą działać nie tylko „w ramach”, lecz zawsze „na podstawie ustawy”. Jest chyba oczywiste, pisze dalej autor, w kategoriach ,zaspokajania potrzeb wspólnoty", że takie podejście jest znacznie mniej skuteczne aniżeli podejście otwarte, pozwalające samodzielnie określać cele (korzyści) publiczne i swobodnie dobierać środki do celów, z uwzględnieniem — nikt tego nie kwestionuje — różnych ograniczeń prawnych ${ }^{14}$.

Współcześnie w obszarze badań nad samorządem terytorialnym nauka prawa administracyjnego i nauka administracji wydzielają określone problemy podstawowe. J. Boć stawia następujące pytania: Co jest na początku: państwo czy jego element terytorialny? Co jest ważniejsze: efektywność centralizacji czy sama decentralizacja niezależnie od jej efektywności? Co jest regułą: sama autonomia czy zwierzchność nadzorcza państwa? Czy o sprawach wyłącznych części ma decydować sama ta część, czy całość, której ta część jest elementem? Czy zakres i treść spraw wyłącznych części ustalane są przez samą tę część, czy przez całość? Jak określać autonomię: czy przez przydanie jej możliwości, czy poczynając od ograniczeń? Czy podmiotom zdecentralizowanym dawać kompetencje, czy i określać cele? ${ }^{15}$

Przy toczone gwoli przykładu poglądy prawoznawstwa dowodzą, że tematyka samorządu terytorialnego zajmuje ważne miejsce w nauce prawa administracyjnego oraz naukach o administracji. Stanowisko prawne samorządu powszechnego stale ewoluuje i jest także badane na gruncie norm ustrojowych i prawa międzynarodowego, które mają doniosłe znaczenie w przedmiotowym zakresie. Głos jurysprudencji przekonuje, że samorząd terytorialny jest doniosłym elementem struktury organizacyjnej i działalności państwa demokratycznego państwa prawnego.

14 M. Kulesza, O tym, ile jest decentralizacji w centralizacji, a także o osobliwych nawykach uczonych administratywistów, [w:] Między tradycją a przyszłościa w nauce prawa administracyjnego. Ksiega jubileuszowa dedykowana Profesorowi Janowi Bociowi, red. J. Supernat, Wrocław 2009, s. 410-411. Por. A. Chełmoński, Polski samorzad terytorialny na tle Europejskiej Karty Samorzadu Terytorialnego, [w:] Odrodzenie samorzadu terytorialnego. Budowa społeczeństwa obywatelskiego, red. P. Buczkowski, Poznań 1994, s. 120; E. Wojciechowski, Samorząd terytorialny w warunkach gospodarki rynkowej, Warszawa 1997; S. Dudzik, Działalność gospodarcza samorzadu terytorialnego. Problematyka prawna, Kraków 1998; L. Kieres, Wolność gospodarcza w działalności jednostek samorządu terytorialnego, [w:] Instytucje wspótczesnego prawa administracyjnego, red. I. Niżnik-Dobosz, Kraków 2001, s. 323; M. Stahl, Dorobek orzeczniczy sądów administracyjnych w sprawach samorządowych, „Zeszyty Naukowe Sądownictwa Administracyjnego” 2010, nr 5-6, s. 402.

15 J. Boć, Administracja samorządu terytorialnego, [w:] A. Błaś, J. Boć (red.), J. Jeżewski, Nauka administracji, Wrocław 2013, s. 61. Por. J. Zimmermann, Aksjomaty prawa administracyjnego, Warszawa 2013; K. Kokocińska, Prawny mechanizm prowadzenia polityki rozwoju w zdecentralizowanych strukturach władzy publicznej, Poznań 2014. 


\section{SAMORZĄD TERYTORIALNY NA TLE WYBRANEJ PRAKTYKI}

Znaczenia właściwej władzy sądowniczej dla sytuacji człowieka oraz prawidłowego funkcjonowania państwa, w tym samorządu terytorialnego, nie ma potrzeby z oczywistych względów dokładniej uzasadniaćc ${ }^{16}$. Wymownie o tym świadczy zwłaszcza kontrola sprawowana przez sądy administracyjne ${ }^{17}$.

$\mathrm{Na}$ akty i czynności samorządowych kolegiów odwoławczych wpłynęło 16377 skarg, co stanowi 23,36\% ogólnego wpływu skarg na akty i czynności. Z liczby tej sądy załatwiły wyrokiem 11723 skargi, z czego 3555 skarg uwzględniły (30,33\%). Dla porównania, w 2015 roku wpłynęły 16883 skargi na akty i czynności samorządowych kolegiów odwoławczych, w 2014 roku - 19 635, w 2013 roku - 19 308, a w 2012 roku - 16 217. Z przedstawionych danych wynika, że liczba skarg na rozstrzygnięcia samorządowych kolegiów odwoławczych w ostatnim roku zmalała, natomiast liczba rozstrzygnięć SKO wyeliminowanych z obrotu prawnego utrzymuje się na podobnym poziomie, czyli około $30 \%$.

W sprawach ze skarg dotyczących samorządu terytorialnego do sądów wpłynęło 2406 skarg (3,14\% ogółu wpływu skarg). Wyrokiem załatwiono 1529 skarg, z czego uwzględniono 947 skarg (61,94\%). Dla porównania, w 2015 roku sądy załatwiły 1788 spraw, uwzględnionych zostało 1078 skarg (60,29\%), a w 2014 roku sądy załatwiły 1735 takich skarg, z czego uwzględniły 985 skarg (56,77\%).

Samorządu gminnego dotyczyły 2082 skargi. Wyrokiem załatwiono 1362 skargi, z czego uwzględniono 849 (62,33\%). Spośród 1494 skarg wniesionych w trybie art. 101 i 101a ustawy z dnia 8 marca 1990 roku o samorządzie gminnym ${ }^{18} 830$ skarg załatwiono wyrokiem, w tym uwzględniono 505 (60,84\%). Skarg organów nadzorczych na uchwały organów gmin w trybie art. 93 ust. 1 u.s.g. wpłynęło 337, z czego wyrokiem załatwiono 320 skarg, w tym uwzględniono 279 $(87,19 \%)$. Natomiast liczba skarg organów gminy na czynności nadzorcze wyniosła 251, z czego wyrokiem załatwiono 212 skarg, w tym uwzględniono 65 (30,66\%).

16 Por. L. Kieres, Niezawisty, bezstronny i niezależny sąd z perspektywy publicznego prawa gospodarczego, „Przegląd Prawa i Administracji” 103, 2015, s. 133; M. Safjan, Polityka a Trybunat Konstytucyjny. Konstytucja — ostatni środek obrony przed polityka, „Ruch Prawniczy, Ekonomiczny i Socjologiczny" 2016, z. 1, s. 37. Por. B. Hełczyński - Pierwszy Prezes Najwyższego Trybunału Administracyjnego. Przemówienie, Monitor Polski z dnia 1 lutego 1934 roku, nr 29, s. 4; P. Winczorek, Dyskusja wokót podstawowych zasad ustroju RP w Komisji Konstytucyjnej Zgromadzenia Narodowego, „Ruch Prawniczy, Ekonomiczny i Socjologiczny” 1995, z. 2, s. 11; H. Zięba-Załucka, Władza ustawodawcza, wykonawcza i sądownicza w Konstytucji Rzeczypospolitej Polskiej, Warszawa 2002; E. Łętowska, J. Łętowski, Co wynika dla sądów z konstytucyjnej zasady podziału władz, [w:] Konstytucja i gwarancje jej przestrzegania. Ksiega pamiątkowa ku czci Prof. Janiny Zakrzewskiej, red. J. Trzciński, A. Jankiewicz, Warszawa 1996, s. 383; S. Wronkowska, Kilka tez o instrumentalizacji prawa i ochronie przed nia, „Przegląd Prawa i Administracji” 110, 2017, s. 107; J. Stępień, Cała wstecz, [w:] Konstytucja w państwie demokratycznym, red. S. Patyra, M. Sadowski, K. Urbaniak, Poznań 2017, s. 301.

17 Informacja o działalności Sądu Najwyższego w roku 2016, Warszawa 2017, s. 17-18.

18 Dz.U. z 2013 r. poz. 594 ze zm. (dalej: u.s.g.). 
Największy wpływ skarg odnotowano w WSA w Warszawie - 361, w WSA w Poznaniu - 230, w WSA w Gliwicach — 199, natomiast najmniej skarg wpłynęło do WSA w Białymstoku - 39 oraz do WSA w Kielcach - 43.

Do wojewódzkich sądów administracyjnych wpłynęło 216 skarg dotyczących samorządu powiatowego, wyrokiem załatwiono 116 skarg, z czego uwzględniono 65 (56,03\%). Spośród 127 skarg wniesionych w trybie art. 87 i 88 ustawy z dnia 5 czerwca 1998 roku o samorządzie powiatowym ${ }^{19}$ załatwiono wyrokiem 67, w tym uwzględniono 40 (59,70\%). Skarg organów nadzorczych na uchwały organów powiatów w trybie art. 81 ust. 1 u.s.p. wpłynęło 21 , z czego załatwiono wyrokiem 14, w tym uwzględniono 11 (78,57\%). Natomiast liczba skarg organów powiatów na czynności nadzorcze wyniosła 68 , z czego załatwiono wyrokiem 35 , w tym uwzględniono 14 (40\%).

Wpływ skarg dotyczących samorządu województwa ${ }^{20}$ wyniósł 108 . Wyrokiem załatwiono 51 skarg, z czego uwzględniono 33 (64,71\%). Spośród 77 skarg wniesionych w trybie art. 90 i 91 ustawy z dnia 5 czerwca 1998 roku o samorządzie województwa wyrokiem załatwiono 37, w tym uwzględniono 28 (75,68\%). Skarg organów nadzorczych na uchwały organów województwa w trybie art. $82 \mathrm{c}$ ust. 1 u.s.w. wpłynęło 11, z czego wyrokiem załatwiono 5, w tym uwzględniono $3(60 \%)$. Natomiast skarg organów województwa na czynności nadzorcze wpłynęło 20, wyrokiem załatwiono 9, w tym uwzględniono $2(22,22 \%)$.

Ogółem załatwiono 2127 skarg na działalność uchwałodawczą samorządu gminnego, uwzględniono 849 skarg (39,92\%); samorządu powiatowego - 190 skarg, w tym uwzględniono 65 skarg (34,21\%); natomiast samorządu województwa - 97 skarg, w tym uwzględniono 33 skargi $(34,02 \%)^{21}$.

Trybunał Konstytucyjny (TK) w kontekście nadzoru nad działalnością samorządu terytorialnego stwierdza, że kryterium zgodności z prawem (legalności) odnosi się do wszystkich postaci działalności komunalnej, co w pełni harmonizuje z omówionymi tu zasadami i przepisami konstytucyjnymi. Konstatacja ta jest zbieżna z linią orzecznictwa konstytucyjnego europejskich państw demokratycznych. Tytułem przykładu wskazać można na pogląd Francuskiej Rady Konstytucyjnej, że kontrola legalności jest wystarczająca do zapewnienia poszanowania przez społeczności lokalne prerogatyw państwa, ale pod warunkiem że jest efektywna. Warunkiem zaś efektywności takiej kontroli jest niewątpliwie objęcie nią całego zakresu działalności jednostek kontrolowanych. Kryterium zgodności z prawem (legalności) jest w szczególności wspólne nadzorowi nad wykonywaniem przez jednostki samorządu terytorialnego zadań własnych i zadań zleconych. Różnica polega natomiast na tym, że w sprawach zleconych nadzór sprawowany jest „ponadto” na podstawie kryteriów celowości, rzetelności i gospodarności.

19 Dz.U. z 2013 r. poz. 595 ze zm. (dalej: u.s.p.).

20 Dz.U. z 2013 r. poz. 596 ze zm. (dalej: u.s.w.).

21 Informacja o działalności Sądu Najwyższego w roku 2016, Warszawa 2017, s. 17-18. 
Wyraz „ponadto” oznacza, że również nadzór nad wykonywaniem zadań zleconych sprawowany jest na podstawie kryterium zgodności z prawem. Wprowadzenie przez polskiego ustawodawcę dalszych kryteriów (celowości, rzetelności i gospodarności) do nadzoru nad wykonywaniem zadań zleconych pozostaje w zgodności z EKSL, która w art. 8 ust. 2 stanowi, że „kontrola administracyjna może uwzględniać także kryterium celowości; jest ona sprawowana przez władze szczebla wyższego i dotyczy zadań zleconych"22.

W kontekście tego należy wskazać na uchwałę z dnia 16 lutego 2016 roku, I OPS 2/15. Naczelny Sąd Administracyjny (NSA) stwierdził w niej, odwołując się do orzecznictwa trybunalskiego, że prawo do sądu, o którym mowa w art. 45 ust. 1 i art. 77 ust. 2 Konstytucji, nie jest prawem podmiotowym jednostek samorządu terytorialnego. Nie oznacza to, że prawo to tym jednostkom nigdy nie przysługuje. Niemniej jednak jedynie wtedy, gdy jednostki te znajdą się w sytuacji charakterystycznej dla człowieka i obywatela, a więc w sytuacji adresata działań władczych organów administracji publicznej. Natomiast sytuację prawną jednostek samorządu terytorialnego jako podmiotów realizujących zadania publiczne kreuje zasada samodzielności (art. 165 Konstytucji). NSA podkreślił, że pojęcia „ochrona sądowej samodzielności jednostek samorządu terytorialnego" i ,prawo do sądu" nie są tożsame. Prawo do sądu jest prawem podmiotowym człowieka i obywatela. Natomiast pojęcie sądowej ochrony samodzielności akcentuje aspekt przedmiotowy mechanizmów ochrony ukierunkowanych na zapewnienie samodzielnego i zgodnego z prawem wykonywania zadań publicznych, zakładając pozostawienie ustawodawcy szerszej swobody co do wyboru sposobów jej urzeczywistnienia. Ochrona sądowa w rozumieniu art. 165 ust. 2 Konstytucji obejmuje tę sferę działania jednostek samorządu terytorialnego, w której Konstytucja zapewnia im samodzielność działania. Chroni te jednostki przed bezprawnymi ingerencjami organów nadzoru w wykonywanie zadań przez organy samorządu terytorialnego. $Z$ tego względu jednostki samorządu tery torialnego mają zdolność sądową w postępowaniu cywilnym, mogą też dochodzić swoich praw w postępowaniu sądowoadministracyjnym $w$ sytuacjach określonych w p.p.s.a. ${ }^{23}$, a więc gdy są one adresatami decyzji administracyjnych lub innych aktów wymienionych w art. $3 \S 2$ pkt 2-4 tej ustawy, a także gdy są adresatami aktów nadzoru. Natomiast sądowa ochrona samodzielności jednostek samorządu terytorialnego nie wymaga zapewnienia tym jednostkom statusu strony w postępowaniu sądowoadministracyjnym ani przyznania im prawa do wniesienia skargi na decyzje organu odwoławczego, gdy jednostka ta nie występuje jako adresat działań wład-

22 Uchwała Trybunału Konstytucyjnego z dnia 27 września 1994 r., sygn. W. 10/93, tekst sentencji — Dz.U. z 1994 r. Nr 113, poz. 550.

23 Ustawa z dnia 30 sierpnia 2002 r. Prawo o postępowaniu przed sądami administracyjnymi (Dz.U. z 2017 r. poz. 1369; dalej: p.p.s.a.). 
czych innych organów władzy publicznej, lecz sama podejmuje takie działania wobec innych podmiotów ${ }^{24}$.

$\mathrm{W}$ bardzo istotnym - dla funkcjonowania samorządu terytorialnego - wyroku z dnia 20 lutego 2015 roku, V CSK 295/14, Sąd Najwyższy (SN) wyjaśnił charakter prawny roszczenia, określonego w art. 49 ust. 6 ustawy z dnia 13 listopada 2003 roku o dochodach jednostek samorządu terytorialnego ${ }^{25}$, którego przedmiotem jest żądanie zasądzenia zwrotu kosztów poniesionych przez tę jednostkę na wykonanie zadania zleconego z zakresu administracji rządowej, niepokrytych przez dotację celową. Wskazał, że przepis ten stanowi samodzielną podstawę roszczenia bez potrzeby odwołania się do art. 417 k.c., jeżeli przekazana dotacja celowa nie zapewnia pełnego i terminowego wykonania zleconych zadań. Roszczenie mające podstawę $\mathrm{w}$ tym przepisie nie jest bowiem związane $\mathrm{z}$ wykonywaniem zadań własnych, ale z wykonywaniem zadań zleconych z zakresu administracji rządowej i skierowane nie przeciwko osobom trzecim, z którymi jako zarządca nieruchomości może wchodzić w stosunki obligacyjne, lecz przeciwko Skarbowi Państwa jako podmiotowi finansującemu wykonanie zadań zleconych. Powiat, wykonując zadanie zlecone ustawą dotyczące zarządu nieruchomościami Skarbu Państwa, nie działa zatem jako przedsiębiorca, ale realizuje zadania wynikające z polityki państwa. W konsekwencji Sąd Najwyższy uznał, że roszczenie to nie ma związku z prowadzeniem działalności gospodarczej, zatem podlega przedawnieniu na zasadach ogólnych, określonych $\mathrm{w}$ art. 118 k.c. ${ }^{26}$

Na uwagę zasługuje też wyrok z dnia 2 marca 2007 roku, sygn. akt I OSK 536/06, w którym NSA wskazał, że w początkowym okresie obowiązywania ustawy z dnia 13 października 1998 roku - Przepisy wprowadzające ustawy reformujące administrację publiczną ${ }^{27}$, pojęcie władania, występujące między innymi w art. 60 ust. 1 tej ustawy, było identyfikowane z pojęciem „faktyczne władanie" w rozumieniu cywilistycznym. Następnie nastąpiła zmiana linii orzecznictwa, a nadto podobne stanowisko zostało wyrażone w wyroku Sądu Najwyższego z dnia 4 grudnia 2002 roku, sygn. akt III RN 206/01, w którym przyjęto, że pojęcie „władanie” dotyczyć może tylko takiego „władztwa nad rzeczą, które daje władającemu możliwość samodzielnego korzystania z nieruchomości państwowej, zgodnie z wymogami prawidłowej gospodarki, czyli takich form władztwa nad mieniem Skarbu Państwa, które zawierało w sobie wiele cech właściwych dla wykonywania władztwa przez właściciela”. NSA podkreślił, że pogląd Sądu Najwyższego przyjął się w orzecznictwie sądów administracyjnych, które zajęły stanowisko, iż faktyczne dysponowanie mieniem, bez tytułu prawnego, nie może

24 Informacja o działalności sądów administracyjnych w 2016 roku, Warszawa 2017, s. 285.

25 Ustawa z dnia 13 listopada 2003 r. o dochodach jednostek samorządu terytorialnego (Dz.U. z 2010 r. Nr 80, poz. 526 z późn. zm.).

26 Informacja o działalności Sądu Najwyższego w roku 2015, Warszawa 2016, s. 47-48.

27 Ustawa z dnia 13 października 1998 r. — Przepisy wprowadzające ustawy reformujące administrację publiczną (Dz.U. Nr 133, poz. 872 z późn. zm.). 
być podstawą do zastosowania art. 60 ustawy Przepisy wprowadzające ustawy reformujące administrację publiczną ${ }^{28}$.

Natomiast w wyrokach z dnia: 7 kwietnia 2005 roku, sygn. akt OSK 1356/04, i 11 stycznia 2005 roku, sygn. akt OSK 1013/04, NSA odniósł się do kwestii charakteru normatywnego załącznika uchwały i uznał, że nie ma oparcia w obowiązujących przepisach stwierdzenie, iż załącznik do uchwały wydanej na podstawie przepisów ustawowych nie ma charakteru normatywnego, a tym samym, że zamieszczenie statutu województwa w załączniku do uchwały w sprawie przyjęcia statutu stanowi istotne naruszenie prawa i pozbawia ten akt rangi obowiązującego przepisu prawa miejscowego. Zdaniem NSA żaden z przepisów nie zastrzega, że zamieszczenie w załączniku do uchwały przepisów merytorycznych powoduje, że przepisy te nie mają charakteru normatywnego. $Z$ kolei w wyroku z dnia 28 czerwca 2005 roku, sygn. akt OSK 1733/04, NSA stwierdził, że interes skarżących, o którym mowa w art. 101 ust. 1 u.s.g., musi być naruszony bezpośrednio i skarżący nie może zarzucać uchwale czy konkretnemu jej przepisowi hipotetycznego, a więc nie rzeczywistego naruszania swojego indywidualnego, konkretnie rozumianego interesu. W tym NSA nie zgodził się z poglądem, by przepisy załącznika do statutu ograniczające liczbę obecnych na sali obrad rady miejskiej do liczby miejsc siedzących, jak również nakaz rejestracji obrad rady za pomocą urządzeń zapisujących obraz i dźwięk wyłącznie z miejsc przeznaczonych dla publiczności naruszały przepisy art. 54 i 61 Konstytucji oraz art. 11b u.s.g. Przepisy te nie definiują jawności, ale mają charakter jedynie swego rodzaju dyrektyw proceduralnych, uregulowań organizacyjno-technicznych, które nie ograniczają, nie wyłączają prawa do informacji, lecz wskazują jedynie na sposób urzeczywistnienia materialnej treści tego przepisu ${ }^{29}$.

Przytoczone judykaty potwierdzają, że funkcjonowanie samorządu terytorialnego opiera się na zróżnicowanych podstawach prawnych i znajduje odpowiedni wyraz w orzeczniczej działalności wszystkich segmentów władzy sądowniczej. Wzmiankowane zjawisko obejmuje stanowienie i stosowanie norm prawa właściwego jednostkom samorządu powszechnego. Władza sądownicza kontroluje działalność samorządu terytorialnego jako podmiotu władzy publicznej, ale jednocześnie stanowi gwarancję jego pozycji prawnej określonej ustawą zasadniczą i wiążące nasze państwo prawo międzynarodowe.

\section{WNIOSKI KOŃCOWE}

Zagadnienia prawne samorządu terytorialnego są stałym przedmiotem zainteresowania prawoznawstwa. Wybiórczy z założenia przegląd opinii naukowych potwierdza, że doktryna obserwuje oraz analizuje zachodzące w tym zakresie

28 Informacja o działalności sądów administracyjnych w 2007 roku, Warszawa 2008, s. 150.

29 Informacja o działalności sądów administracyjnych w 2005 roku, Warszawa 2006, s. 134-135. 
przeobrażenia. Konstytucyjnoprawne i prawnomiędzynarodowe uwarunkowania sytuują samorząd terytorialny jako ważny oraz trwały element struktury organizacyjnej nowoczesnego państwa, którego pozycję w systemie władz publicznych dookreśla przede wszystkim ustawodawca zwykły. Piśmiennictwo niejednokrotnie zwracało uwagę, że wzmiankowane dookreślanie statusu samorządu terytorialnego przez czynnik parlamentarny i w drodze rozporządzeń skutkuje niekiedy odchodzeniem w praktyce od wymogów konstytucyjnoprawnych i prawnomiędzynarodowych. Od C. Znamierowskiego wiemy, że nie tylko legislator rządowy, ale także normodawca parlamentarny może zagrażać bezpieczeństwu prawnemu nie mniej niż monarcha nieograniczony ${ }^{30}$. Dlatego tak doniosłe jest zagwarantowanie funkcjonowania bezstronnej, niezależnej, niezawisłej i sprawnej władzy sądowniczej, która zapewnia realną ochronę i realizację konstytucyjnych oraz międzynarodowych zasad (wartości) stanowiących nieodzowny fundament samorządu terytorialnego w nowoczesnym demokratycznym państwie prawnym. Wybiórczo przytoczone judykaty potwierdzają, że samorząd powszechny jest uczestnikiem różnej natury sytuacji prawnych będących następstwem jego swoistej pozycji jurydycznej oraz przydzielonych mu do wykonywania zadań publicznych w państwie.

Poruszone w niniejszym opracowaniu kwestie nie wyczerpują szerokiej gamy zagadnień jurydycznych znamiennych dla tej tematyki. Tytułem przykładu wskażmy na zjawisko przenikania publicznoprawnej i prywatnoprawnej sfery regulacyjnej w sprawach wykonywania na przykład działalności komunalnej z wykorzystaniem praw majątkowych przynależnych jednostkom samorządu terytorialnego. Zdaniem L. Kieresa owa materia została istotnie przewartościowana w porównaniu do uprzedniej formacji - systemu gospodarki scentralizowanej. Dominację publicznoprawnej metody regulacji obecnie w społecznej gospodarce rynkowej zastąpiło przyjęcie właściwości regulacyjnej prawa cywilnego i jej podstawowych instytucji prawnych, które ujmują sytuację majątkową stron stosunków obligacyjnych lub też obowiązują przy wykonywaniu uprawnień prawnorzeczowych. Oddziaływanie regulacji publicznoprawnych, według autora, ma mieć charakter uzupełniający i wspierający rozwiązania prywatnoprawne. Regulacje publicznoprawne o składnikach mienia podmiotów prywatnych lub też wykorzystywanych do wykonywania zadań publicznych nawiązują do podstawowych konstrukcji prawa prywatnego i recypują je na grunt stosunków nawiązywanych w procesach zarządu mieniem publicznym ${ }^{31}$.

30 C. Znamierowski, Elita, ustrój, demokracja. Pisma wybrane, Warszawa 2001, s. 115.

31 L. Kieres, Zarzad mieniem publicznym, [w:] System Prawa Administracyjnego, t. 8A. J. Grabowski et al., Publiczne prawo gospodarcze, Warszawa 2013, s. 709. 


\title{
SOME REMARKS ON THE THEORY AND PRACTICE OF TERRITORIAL SELF-GOVERNMENT
}

\author{
Summary
}

The legal issues of territorial self-government are the subject of interest in jurisprudence. Territorial self-government forms an important and permanent part of the organizational structure of a democratic state ruled by law, which is affected by constitutional and international legal factors. Determining of the status of territorial self-government by means of parliament statutes and ordinances sometimes results in departing from the relevant constitutional and international requirements. That is why it is so important to guarantee the functioning of an impartial, independent and efficient judicial power in the field of the organization and functioning of territorial self-government in a modern state.

Keywords: territorial self-government, democratic state ruled by law, judicial power

\section{BIBLIOGRAFIA}

60 lat Rady Europy. Tworzenie i stosowanie standardów prawnych, red. H. Machińska, Warszawa 2009.

Aktualne problemy funkcjonowania samorzadu terytorialnego, red. E. Ura, E. Ferent, S. Pieprzny, Rzeszów-Sandomierz 2017.

B. Hełczyński - Pierwszy Prezes Najwyższego Trybunału Administracyjnego. Przemówienie, Monitor Polski z dnia 1 lutego 1934 r., nr 29.

Benoît-Rohmer F., Klebes H., Prawo Rady Europy. W stronę ogólnoeuropejskiej przestrzeni prawnej, przeł. M.A. Nowicki, Warszawa 2006.

Bigo T., Związki publiczno-prawne w świetle ustawodawstwa polskiego, Warszawa 1928.

Boć J., Administracja samorządu terytorialnego, [w:] A. Błaś, J. Boć (red.), J. Jeżewski, Nauka administracji, Wrocław 2013.

Chełmoński A., Polski samorząd terytorialny na tle Europejskiej Karty Samorzadu Terytorialnego, [w:] Odrodzenie Samorządu Terytorialnego. Budowa Spoleczeństwa Obywatelskiego, red. P. Buczkowski, Poznań 1994.

Chorąży K., Zagadnienia ustroju lokalnego Francji, Lublin 1998.

Cieśliński A., Stosowanie prawa wspólnotowego w praktyce organów samorządowych, [w:] Samorząd terytorialny w Polsce wobec wyzwań integracji europejskiej, red. J.P. Tarno, Zielona Góra 2003.

Dembiński M., Osobowość publiczno-prawna samorządu w świetle metody dogmatycznej i socjologicznej, Wilno 1934.

Dolnicki B., Modele samorządu terytorialnego w Europie i w Polsce, Katowice 1994.

Dolnicki B., Nadzór nad samorzadem terytorialnym, Katowice 1993.

Dudzik S., Działalność gospodarcza samorzadu terytorialnego. Problematyka prawna, Kraków 1998.

Fundowicz S., Decentralizacja administracji publicznej w Polsce, Lublin 2005.

Izdebski H., Rada Europy. Organizacja demokratycznych państw Europy i jej znaczenie dla Polski, Warszawa 1996.

Jaskiernia J., Zgromadzenie Parlamentarne Rady Europy, Warszawa 2000. 
Jeżewski J., Dekoncentracja terytorialna administracji jako zasada prawa administracyjnego we Francji, Wrocław 2004.

Jędrzejewski S., Nowicki H., Kontrola administracji publicznej. Kontrola a nadzór. Struktura systemu. Instytucje, Toruń 1995.

Kaczmarek J., Rada Europy, Wrocław 2002.

Kieres L., Analiza zgodności polskiego prawa samorzadu terytorialnego z Europejska Karta Samorzadu Terytorialnego, „Samorząd Terytorialny” 1998, nr 9.

Kieres L., Niezawisty, bezstronny i niezależny sąd z perspektywy publicznego prawa gospodarczego, „Przegląd Prawa i Administracji” 103, 2015.

Kieres L., Prawo europejskie wobec samorzadu terytorialnego, [w:] Samorzad - finanse - nadzór i kontrola. XX-lecie Regionalnych Izb Obrachunkokwych, red. R.P. Krawczyk, M. Stec, Warszawa 2013.

Kieres L., Wolność gospodarcza w działalności jednostek samorzadu terytorialnego, [w:] Instytucje wspótczesnego prawa administracyjnego, red. I. Niżnik-Dobosz, Kraków 2001.

Kieres L., Zarzad mieniem publicznym, [w:] System Prawa Administracyjnego, t. 8A. J. Grabowski et al., Publiczne prawo gospodarcze, Warszawa 2013.

Kokocińska K., Prawny mechanizm prowadzenia polityki rozwoju w zdecentralizowanych strukturach władzy publicznej, Poznań 2014.

Korczak J., Konstytucyjne podstawy struktury i funkcji samorządu terytorialnego, [w:] System Prawa Administracyjnego, t. 2. S. Biernat et al., Konstytucyjne podstawy funkcjonowania administracji publicznej, Warszawa 2012.

Kulesza M., Niektóre zagadnienia prawne definicji samorządu terytorialnego, „Państwo i Prawo” 1990, nr 1.

Kulesza M., O tym, ile jest decentralizacji w centralizacji, a także o osobliwych nawykach uczonych administratywistów, [w:] Między tradycją a przyszłościa w nauce prawa administracyjnego. Księga jubileuszowa dedykowana Profesorowi Janowi Bociowi, red. J. Supernat, Wrocław 2009.

Kulesza M., Galus K., Tułowiecki M., Harmonizacja prawa polskiego w zakresie przepisów dotyczacych samorzadu terytorialnego, Warszawa 2001.

Leoński Z., Samorząd w Polsce. Istota. Formy. Zadania, Poznań 1998.

Lisowski P., Relacje strukturalne w polskim samorzadzie terytorialnym, Wrocław 2013.

Longchamps F., Co każdy obywatel powinien wiedzieć o administracji państwowej, Warszawa 1948.

Łętowska E., Łętowski J., Co wynika dla sądów z konstytucyjnej zasady podziału władz, [w:] Konstytucja i gwarancje jej przestrzegania. Księga pamiątkowa ku czci Prof. Janiny Zakrzewskiej, red. J. Trzciński, A. Jankiewicz, Warszawa 1996.

Miemiec M., Gmina w administracji publicznej Republiki Federalnej Niemiec, Wrocław 2007.

Niczyporuk J., Dekoncentracja administracji publicznej, Lublin 2006.

Niewiadomski Z., Samorzad terytorialny w Konstytucji RP [komentarz do art. 15, art. 16 oraz do art. 163-172], „Samorząd Terytorialny” 2002, nr 3.

Niewiadomski Z., Samorząd w warunkach państwa kapitalistycznego, Warszawa 1988.

Panejko J., Geneza i podstawy samorzadu europejskiego, Paryż 1926.

Polska i Rada Europy: 1990-2005, red. H. Machińska, Warszawa 2005.

Rabska T., Samorzad terytorialny w strukturze aparatu państwa (perspektywy przebudowy administracji lokalnej), „Ruch Prawniczy, Ekonomiczny i Socjologiczny” 1993, z. 3.

Regulski J., Samorząd III Rzeczypospolitej. Koncepcje i realizacja, Warszawa 2000.

Safjan M., Polityka a Trybunat Konstytucyjny. Konstytucja — ostatni środek obrony przed polityka, „Ruch Prawniczy, Ekonomiczny i Socjologiczny” 2016, z. 1.

Samorzad terytorialny i administracja w wybranych krajach. Gmina w państwach Europy Zachodniej, red. J. Jeżewski, Wrocław 1999. 
Skrzydło-Niżnik I., Model ustroju samorzadu terytorialnego w Polsce na tle zagadnień ustrojowego prawa administracyjnego, Kraków 2007.

Stahl M., Dorobek orzeczniczy sądów administracyjnych w sprawach samorządowych, „Zeszyty Naukowe Sądownictwa Administracyjnego" 2010, nr 5-6.

Starościak J., Decentralizacja administracji, Warszawa 1960.

Stępień J., Cała wstecz, [w:] Konstytucja w państwie demokratycznym, red. S. Patyra, M. Sadowski, K. Urbaniak, Poznań 2017.

Stępień J., Samorząd terytorialny w konstytucyjnym ustroju państwa, [w:] Księga XX-lecia orzecznictwa Trybunatu Konstytucyjnego, red. M. Zubik, Warszawa 2006.

Studia nad samorząem terytorialnym, red. A. Błaś, Wrocław 2002.

Szewc T., Dostosowanie prawa polskiego do zasad Europejskiej Karty Samorzadu Terytorialnego, Bydgoszcz 2006.

Wacholz W.S., Istota i prawo zwiazków publicznych (publiczne osoby zwiazkowe), Warszawa 1928.

Winczorek P., Dyskusja wokót podstawowych zasad ustroju RP w Komisji Konstytucyjnej Zgromadzenia Narodowego, „Ruch Prawniczy, Ekonomiczny i Socjologiczny” 1995, z. 2.

Wojciechowski E., Samorząd terytorialny w warunkach gospodarki rynkowej, Warszawa 1997.

Wronkowska S., Kilka tez o instrumentalizacji prawa i ochronie przed nia, „Przegląd Prawa i Administracji” 110, 2017.

Z I-go Polskiego Kongresu Nauk Administracyjnych w Poznaniu (20-23 czerwca 1929), „Ruch Prawniczy, Ekonomiczny i Socjologiczny" 1929.

Zdyb M., Samorząd a państwo. Nadzór nad samorządem, Lublin 1993.

Zięba-Załucka H., Władza ustawodawcza, wykonawcza i sądownicza w Konstytucji Rzeczypospolitej Polskiej, Warszawa 2002.

Zimmermann J., Aksjomaty prawa administracyjnego, Warszawa 2013.

Zimmermann M., Nauka administracji i polskie prawo administracyjne, cz. 1, Poznań 1949.

Znamierowski C., Elita, ustrój, demokracja. Pisma wybrane, Warszawa 2001. 